\title{
Implementation of Cooperative Learning Models Can Improve Student Learning Outcomes in Class V Animal Lifestyle Materials of SD Negeri 02 Kebagusan
}

\author{
Krispita Evalia \\ SD Negeri 02 Kebagusan \\ krispitaevalia11@gmail.com
}

\section{Article History}

accepted 14/11/2020

\begin{abstract}
Science learning outcomes for grade V SD Negeri 02 Kebagusan are still low. This is due to the less interesting teaching and learning process. So that the students do not understand the material in science material about the life cycle of animals. Efforts that can be made by the teacher so that the teaching and learning process is fun is that the teacher must use various learning models that attract students. These low learning outcomes cause problems that must be solved by using cooperative learning models to improve student learning outcomes. To improve student learning outcomes it is used to improve the learning process through research using planning, implementation, observation, and reflection steps. From that reflection, the repair process was carried out. From the results of the improvement of the learning process for 2 cycles, it turns out that the use of the cooperative learning model can improve the learning outcomes of class V SD Negeri 02 Kebagusan. It can be seen that the learning outcomes in cycle 1 increased $71 \%$ and cycle II increased to $83 \%$. To improve teacher learning outcomes can use cooperative learning models in science learning in class $V$
\end{abstract}

Keywords: Learning outcomes, cooperative learning models, science

\begin{abstract}
Abstrak
Hasil belajar IPA pada siswa kelas V SD Negeri 02 Kebagusan masih rendah. Hal ini disebabkan proses belajar mengajar yang kurang menarik. Sehingga mengakibatkan siswa kurang memahami materi pada materi IPA tentang daur hidup hewan. Upaya yang dapat dilakukan guru agar proses belajar mengajar menyenangkan adalah guru harus menggunakan berbagai model pembelajaran yang menarik siswa. Hasil belajar yang rendah ini menimbulkan permasalahan yang harus dipecahkan dengan menggunakan model pembelajaran kooperatif learning dapat meningkatkan hasil belajar siswa. Untuk meningkatkan hasil belajar siswa diginakan perbaikan proses pembelajaran melalui penelitian dengan menggunakan langkah langkah perencanaa, pelaksanaan, observasi, dan refleksi. Dari refleksi itu proses perbaikan dilakukan. Dari hasil perbaikan proses pembelajaran selama 2 siklus ternyata penggunaan model pembelajaran kooperatif learning dapat meningkatkan hasil belajar IPA kelas V SD Negeri 02 Kebagusan. Terlihat hasil belajar siklus 1 meningkat $71 \%$ dan siklus II meningkat menjadi $83 \%$. untuk meningkatkan hasil belajar guru dapat menggunakan model pembelajaran kooperatif pada pembelajaran IPA dikelas V.
\end{abstract}

Kata kunci: Hasil belajar, model pembelajaran kooperatif,IPA

Social, Humanities, and Education Studies (SHEs): Conference Series https://jurnal.uns.ac.id/shes

p-ISSN 2620-9284 e-ISSN 2620-9292 


\section{PENDAHULUAN}

Menurut Undang - undang Nomor 20 Tahun 2003 tentang system pendidkan Nasional pasal 3: pendidikan Nasional berfungsi mengembangkan kemampuan dan membentuk watak serta peradaban bangsa, bermartabat dalam rangka mencerdaskan kehidupan bangsa, bertujuan untuk berkembangnya potensi peserta didik agar menjadi manusia beriman dan bertaqwa terhadap Tuhan Yang Maha Esa,berakhlak mulia, sehat, berilmu,dan menjadi warga negara demokratis serta bertanggung jawab(permendibud No.20 tahun 2003)

Didalam membentuk watak bangsa melalui pengembangan kepribadian dan nilai - nilai yang diinginkan, guru memegang peran yang penting. Dari dimensi itulah peran guru sulit untuk digantikan oleh yang lain. Sedangkan dipandang dari dimensi tetap dominan sekalipun teknologi dapat dimanfaatkan dalam proses pembelajaran yang berkembang cepat. Hal ini Karena peran guru tidak dapat digantikan oleh teknologi.

Dalam kegiatan pembelajaran di SD ada berbagai macam muatan pelajaran yang diajarkan kepada pesert didik yang tergabung dalam tematik .dan salah satunya adalah IPA .Materi IPA yang bertujuan agar peserta didik mampu membuat diagram dan mampu membedakan daur hidup tiga jenis hewan yang berbeda secara tepat.

Pada pembelajaran tematik kelas V muatan IPA materi Daur Hidup Hewan, masih mengalami kesulitan sehingga hasil evaluasi yang mengalami kegagalan. Semua ini bukan semata - mata peserta didik akan tetapi kemungkinan rendahnya hasil evaluasi dikarenakan karena guru kurang memahami konsep yang harusnya diberikan kepada siswa. Dengan demikian guru perlu melakukan pembenahan dalam mengajarkan materi.

Dari pengalaman penulis mengajar selama ini diketahui bahwa tingkat penguasaan siswa dalam muatan pelajaran IPA khususnya tentang Daur Hidup Hewan di SD Negeri 02 Kebagusan kecamatan Ampelgading Kabupaten Pemalang menunjukkan hasil yang belum memuaskan, terbukti dari perolehan nilai belum menunjukkan hasil yang signifikan.

Salah satu pelajaran yang menuntut penggunaan model pembelajaran yang sesuai adalah muatan pelajaran pengetahuan alam (IPA) merupakan ilmu yang mempelajari tentang gejala alam berupa fakta., konsep, dan hokum yang telah teruji kebenarannya melalui suatu rangkaian penelitian .pembelajaran IPA yang memberikan kesempatan siswa untuk menjelajah dan memahami alam sekitar secara ilmiah. Pembelajaran IPA dengan memberikan pengalaman langsung dapat menumbuhkan cognitive thingking skill(keterampilan berpikir kognitif),psychomotor skill(keterampilan psikomotorik), dan social skills(keterampilan sosial) (prabowo, 2015)

Penggunaan model pembelajaran harus sesuai dengan materi yang disampaikan , jika tidak sesuai maka tujuan pembelajaran yang diinginkan tidak akan tercapai . hasil belajar IPA juga akan rendah karena peserta didik tidak memahami materi pelajaran yang disampaikan.

Hasil ulangan pembelajaran IPA di kelas V SD Negeri 02 Kebagusan tentang Daur Hidup Hewan yang masih rendah . Dari 22 siswa memperoleh nilai kurang dari 70 sebagai standar KKM atau sekitar 51 persen. Kelompok siswa ini memerlukan perbaikan pembelajaran dengan memperlihatkan segala aspek yang dapat menunjang keberhasilan belajar dan meminimalisir hambatan - hambatan dalam pembelajaran.Dalam proses Penelitian Tindakan Kelas ini peneliti akan meminta peserta didik menganalisis daur hidup hewan melalui metode kooperatif. Dari pengamatan peneliti ketidak mampuan peserta didik terhadap materi yaitu Model pembelajaran yang digunakan guru kurang tepat.

Dari hasil uraian sebelumnya maka dapat diambil suatu analisis masalah dalam perbaikan pembelajaran terhadap materi menganalisis daur hidup hewan antara lain, Penjelasan guru dalam menyampaikan materi kurang jelas, Model pembelajaran yang digunakan guru kurang sesuai sehingga peserta didik kurang begitu tertarik. Sesuai 
dengan latar belakang dan identifikasi permasalah di atas, di susun rumusan masalah sebagai berikut:

"Apakah dengan penerapan model pembelajaran kooperatif dapat meningkatkan hasil belajar siswa pada memahami materi daur hidup hewan di kelas V SD Negeri 02 Kebagusan kecamatan Ampelgading Kabupaten Pemalang?

Sesuai dengan permasalahan di atas, peneliti ini bertujuan untuk:

"Untuk meningkatkanhasil belajar peserta didik kelas $\mathrm{V}$ pada pembelajaran IPA materi Daur Hidup Hewan melalui penerapan model pembelajaran kooperatif di SD Negeri 02 Kebagusan, kecamatan Ampelgading Kabupaten Pemalang"

Menurut sujana (2009:3)hasil belajar peserta didik pada hakekatnya adalah perubahan tingkah laku. Tingkah laku sebagai hasil belajar dalam pengertian yang luas mencakup bidang kognitif, afektif dan psikomotoris. Selain perubahan tingkah laku , jika disekolah hasil belajar biasanya dinilai dengan angka. Peserta didik akan mendapat nilai yang akan menggambarkan keberhasilan dalam belajar. Pelajaran IPA pada peneliti ini menggunakan model pembelajaran kooperatif learning, yaitu suatu strategi belajar mengajar yang menekankan pada sikap atau perilaku bersama dalam bekerja atau membantu diantara sesame dalam struktur kerja sama yang teratur dalam kelompok, yang terdiri dari dua orang atau lebih.

Menurut Anita Lie dalam bukunya "cooperative learning ", bahwa model pembelajaran koopertaif tidak sama dengan sekedar belajar kelompok,tetapi ada unsur - unsur dasar yang membedakannya dengan pembagian kelompok yang dilakukan asal - asalan. Roger Johnson mengatakan bahwa tidak semua kerja sama kelompok bisa dianggap pembelajaran kooperatif, untuk itu harus diterapkan lima unsur model pembelajaran gotong royong.

\section{METODE}

Penelitian ini adalah Penelitian Tindakan Kelas merupakan terjemahan dari classroom action research (CAR), yaitu satu action research yang dilakukan di kelas. Classroom action research diawali dari istilah action research. Dengan menerapkan model pembelajaran kooperatif learning.

Menurut kurt Lewin dalam Kunandar (2011:42)peneliti tindakan kelas ini terdiri empat tahapan dasar yaitu perencanaan (planning), pelaksanaan (acting), pengamatan (observing) dan refleksi(reflecting). Analisis peneliti ini adalah analisis daskriptif kuantitatif kualitatif dimana dalam penelitian ini selain penyajian hasil berupa data maupun angka peneliti juga menentukan bagaimana cara mengelolah hasil penelitian yakni dengan membuat analisisnya dengan menerapkan model penelitian kooperatif learning. Penelitian ini dilaksanakan pada peserta dodik kelas V SD Negeri 02 Kebagusan T ahun pelajaran 2020/2021 selama 2 siklus secara daring dilaksanakan pada tanggal 16 dan 23 November 2020. Teknik pengumpulan data yang dilakukan dengan observasi dan tes. Observasi meliputi keterlaksanaan model pembelajaran kooperatif learning, sikap peserta didik dan keterampilan. untuk hasil belajar menggunakan tes melalui google form.

\section{HASIL DAN PEMBAHASAN}

Bagian ini sebanyak 800-1000 kata. Pada bagian pembahasan, diuraikan hasil kajian/penelitian dan hubungannya dengan kerangka teori atau kajian empirik terdahulu. Pada bagian ini dapat mnyertakan tabel dan gambar secara ringkas. Contoh penyajian tabel dan gambar sebagai berikuterupa hasil pengematan tindakan setiap siklus dan hasil tes formatif. Data tersebut akan dijadikan sebagai tolak ukur keberhasilan dan sebagai pedoman bagi peneliti dalam melakukan peneliti tindakan kelas (PTK)

Dengan demikian peneliti bisa melakukan penilaian yang sesuai dengan sikap, minat, dan kemampuan siswa., sehingga penelitian bisa berjalan dengan baik, yang 
pada akhirnya akan diperoleh hasil penelitian yang baik pula. Untuk itu peneliti membuat deskripsi data per siklus.

1. Deskripsi Siklus 1

Kegiatan perbaikan pembelajaran yang dilaksanakan peneliti pada materi pokok daur hidup hewan adalah penguasaan materi pembelajaran dan pemberian umpan balik serta ketuntasan hasil nilai akhir yang dilaksanakan oleh siswa

Dalam memberikan penjelasan materi pembelajaran peneliti menggunakan metode ceramah dan media berupa teks dan gambar untuk mempermudah pemehaman siswa dan penguasaan siswa terhadap materi pembelajaran seperti siswa memperhatikan penjelasan dari guru, menjawab pertanyaan dari guru dan melakukan tugas dari guru.

Pertemuan dari siklus diakhiri dengan pemberian soal evaluasi kepada siswa sesuai dengan materi yang telah disampaikan dalam pembelajaran.

Tujuan pelaksanaan evaluasi adalah untuk mengetahui tingkat keberhasilan peneliti dalam upaya meningkatkan hasil belajar siswa.

Hasil tes evaluasi siklus 1 sebagai berikut:

a. Siswa yang mendapat nilai kurang dari 70 ada 8 dari 22 siswa atau $36 \%$

b. Siswa yang mendapat nilai 70 atau lebih sebanyak 14 siswa dari 22 siswa atau $64 \%$.

Berdasarkan hasil belajar yang diperoleh tersebut ternyata hasil belajar siswa belum mencapai apa yang diharapkan oleh peneliti. Nilai hasil evaluasi siswa masih banyak yang dibawah standar ketuntasan yaitu 70 , dengan demikian peneliti melakukan peneliti tindakan kelas untuk siklus II.Hasil belajar peserta didik dapat dilihat pada tabel berikut:

Tabel I. Hasil belajar peserta didik siklus 1

\begin{tabular}{ccccc}
\hline No & Nilai & Jumlah Siswa & Jumlah Nilai & $\begin{array}{c}\text { Keteran } \\
\text { gan }\end{array}$ \\
\hline 1 & 50 & 4 & 200 & TT \\
2 & 60 & 4 & 240 & TT \\
3 & 70 & 6 & 420 & T \\
4 & 80 & 4 & 360 & $\mathrm{~T}$ \\
5 & 90 & 3 & 270 & $\mathrm{~T}$ \\
6 & 100 & 1 & 100 & $\mathrm{~T}$ \\
& Jumlah & 22 & 1590 & \\
& Rata-rata & - & 72,27 & \\
\hline
\end{tabular}

Berdasarkan refleksi pada siklus 1 maka diputuskan untuk melanjutkan ke siklus II dikarenakan belum mencapai ketuntasan klasifikasi yang diharapkan.

2. Deskrispi data hasil belajar siklus II

Kegiatan perbaikan pembelajaran siklus ini, dilaksanakan kembali materi pokok. Karena pada materi pokok ini banyak siswa yang belum memahami dan menguasai materi . pada masalah pemahaman dan penguasaan materi dan peneliti menggunakan pembelajaran secara maksimal.

Kegiatan penelitian tindakan kelas ini tetap meminta bantuan teman sejawat , untuk mengamati jalannya proses pembelajaran.

Pertemuan siklus II diakhiri dengan pelaksanaan evaluasi menggunakan google form. Tujuan evaluasi ini untuk mengetahui keberhasilan penelitian dalam upaya meningkatkan hasil belajar siswa.

Hasil evaluasi pada siklus II sebagia berikut:

a. Siswa yang mendapat nilai diatas KKM (70) ada 18 dari 22 siswa atau $82 \%$

b. Siswa yang mendapat nilai kurang dari KKM (70) 4 dari 22 siswa atau $18 \%$ 
Berdasarkan hasil tes ternyata apa yang diharapkan peneliti sudah tercapai , dengan perolehan nilai rata - rata kelas 80

Tabel II. Hasil belajar peserta didik

\begin{tabular}{ccccc}
\hline No & Nilai & $\begin{array}{c}\text { Jumlah } \\
\text { Siswa }\end{array}$ & Jumlah Nilai & Keterangan \\
\hline 1 & 50 & 1 & 50 & TT \\
2 & 60 & 3 & 180 & TT \\
3 & 70 & 2 & 140 & T \\
4 & 80 & 8 & 640 & T \\
5 & 90 & 5 & 450 & T \\
6 & 100 & 3 & 300 & T \\
& Jumlah & 22 & 1760 & \\
& Rata-rata & & 80 & \\
\hline
\end{tabular}

Dari ke dua siklus yang telah dilaksanakan selama 2 pertemuan dapat dipastikan bahwa model pembelajaran kooperatif learning dapat meningkatkan hasil belajar peserta didik pada mupel IPA kelas V di SD Negeri 02 Kebagusan. Hal ini sesuai dengan model pembelajaran kooperatif teknik jigsaw merupakan model pembelajaran kooperatif dimana siswa belajar dalam kelompok kecil yang terdiri 4-6 orang secara heterogen dan kerjasama saling ketergantungan yang positif dan bertanggung jawab atas ketuntasan bagian materi pelajaran yang haris dipelajari dan menyampaikan materi tersebut kepada anggota kelompok lain(Arends,1997)

Jigsaw didesain untuk meningkatkan rasa tanggung jawab siswa terhadap pembelajaran nya sendiri dan juga pembelajaran orang lain. Siswa tidak hanya mempelajari materi yang diberikan, tetapi mereka juga harus siap memberikan dan mengajarkan materi tersebut pada anggota kelompoknya yang lain. Dengan demikian , "siswa saling tergantung satu dengan yang lain dan harus bekerja sama secara kooperatif untuk mempelajari materi yang ditugskan"(Lie,A, 1994)

\section{SIMPULAN}

Penerapan model pembelajaran kooperatif dapat meningkatkan hasil belajar peserta didik kelas $\mathrm{V}$ pada mupel IPA materi daur hidup hewan . peningkatan yang terjadi karena adanya kesan pembelajaran yang dibuat. Pembelajaran yang melibatkan siswa dengan guru akan melahirkan nilai yang akan terbawa dan tercermin terus dalam kehidupan di masyarakat. Pembelajaran yang melibatkan siswa secara aktif dalam kelompok secara bergotong royong (kooperratif) akan menimbulkan suasana belajar partisipatif dan menjadi lebih hidup. Teknik pembelajaran kooperatif dapat mendorong timbulnya gagasan yang lebih bermutu dan dapat meningkatkan kreaktivitas siswa.

Berdasarkan penelitian yang telah dilaksanakan salah satu model pembelajaran yang harus dikuasai guru adalah kooperatif karena model ini sangat cocok digunakan dalam pandemic seperti ini, apalagi dalam kondisi belajar dari rumah. Dengan pembelajaran kooperatif peserta didik akan terdorong menimbulkan gagasan yang lebih bermutu dan dapat meningkatkan kreaktivitas peserta didik.

\section{DAFTAR PUSTAKA}

Ahmad susanto. (2013). Teori belajar dan Pembelajaran di Sekolah Dasar. Jakarta:Kencana Prenada Media Group.

Anita Lie.2007 . cooperatine learning.Jakarta:Grasindo.

Isjoni. (2011) cooperative Learning Efektivitas Pembelajaran Kelompok. Bandung:ALFABETA. 
Kunandar, 2011.langkah mudah penelitian tindakan kelas sebagai pengembangan profesi Guru.Jakarta :PT Raja Grafindo Persada.

Komalasari, Kokom.(2011). Pembelajaran kontekstual konsep dan aplikasi .Bandung : PT Refika Aditama.

Sagala Syaiful,(2013).konsep dan makna pembelajaran.Bandung:Alfabeta

Sudjana, N.2009. penelitian Hasil Proses Belajar mengajar (cetakan ketigabelas) Bandung :PT Remaja Rosdakarya.

Suprijono, Agus. (2010). Cooperative learning Teori dan aplikasi paikem.Yogyakarta :Pustaka Pelajar. 